\title{
Synthesis, Crystal Structure, and Redox and Photophysical Properties of Novel Bisphosphinoaryl Ru ${ }^{\text {II }}$-Terpyridine Complexes
}

\author{
Marcella Gagliardo ${ }^{\dagger}$ Harm P. Dijkstra,${ }^{\dagger}$ Paolo Coppo, ${ }^{\perp}$ Luisa De Cola,${ }^{\perp}$ \\ Martin Lutz, ${ }^{\ddagger}$ Anthony L. Spek,,${ }^{\ddagger}$ Gerard P. M. van Klink,${ }^{\dagger}$ and \\ Gerard van Koten*,† \\ Debye Institute, Department of Metal-Mediated Synthesis, and Bijvoet Center for \\ Biomolecular Research, Department of Crystal and Structural Chemistry, Utrecht University, \\ Padualaan 8, 3584 CH Utrecht, The Netherlands, and Institute of Molecular Chemistry, \\ Molecular Photonic Materials Group, University of Amsterdam, Nieuwe Achtergracht 166, \\ 1018 WV Amsterdam, The Netherlands
}

Received July 5, 2004

\begin{abstract}
Novel organometallic $[\mathrm{Ru}(\mathrm{PCP})($ tpy) $] \mathrm{Cl}$ complexes, containing the terdentate coordinating monoanionic bisphosphinoaryl ligands $\left[\mathrm{C}_{6} \mathrm{H}_{3}\left(\mathrm{CH}_{2} \mathrm{PR}_{2}\right)_{2}-2,6\right]^{-}(\mathrm{PCP})(\mathrm{R}=\mathrm{Ph}(\mathbf{1 1}) ; i \operatorname{Pr}(\mathbf{1 2}))$ and $2,2^{\prime}: 6^{\prime}, 2^{\prime \prime}$-terpyridine, have been synthesized by two different synthetic pathways in good yields. The molecular structure in the solid state of $\left[\mathrm{Ru}\left\{\mathrm{C}_{6} \mathrm{H}_{2}\left(\mathrm{CH}_{2} \mathrm{PPh}_{2}\right)_{2}-2,6\right\}(\right.$ tpy) $](\mathrm{OTf})(\mathbf{1 4})$ has been determined by X-ray crystallography. The spectroscopic and electrochemical properties of the $[\mathrm{Ru}(\mathrm{PCP})(\mathrm{tpy})] \mathrm{Cl}$ complexes were compared with those obtained for $\left[\mathrm{Ru}\left\{\mathrm{C}_{6} \mathrm{H}_{3}\left(\mathrm{CH}_{2} \mathrm{NMe}_{2}\right)_{2}-2,6\right\}(\right.$ tpy $\left.)\right](\mathrm{Cl})$ (3) containing the monoanionic bisaminoaryl ligand $\left[\mathrm{C}_{6} \mathrm{H}_{3}\left(\mathrm{CH}_{2} \mathrm{NMe}_{2}\right)_{2}-2,6\right]^{-}(\mathrm{NCN})$. The obtained results revealed that substitution of the NCNpincer ligand by PCP-pincer ligands offers a powerful tool to tune the redox and photophysical properties as well as the reactivity of the ruthenium(II) metal centers in the resulting photoactive monomeric species.
\end{abstract}

\section{Introduction}

For the past decade, monomeric ruthenium polypyridine complexes have been widely used as efficient photosensitizers in covalently linked multicomponent systems due to their chemical stability, redox properties, and excited state reactivity. ${ }^{1}$ The most common polypyridyl ligands employed as terminal ligands in such species are $2,2^{\prime}$-bipyridine (bpy) and $2,2^{\prime}: 6^{\prime}, 2^{\prime \prime}$-terpyridine (tpy). Considerable attention was focused on the $\left[\mathrm{Ru}(\mathrm{bpy})_{3}\right]^{2+}$ and $\left[\mathrm{Ru}(\text { tpy })_{2}\right]^{2+}$ molecular systems. ${ }^{2} \mathrm{Al}-$ though $\left[\mathrm{Ru}(\text { tpy })_{2}\right]^{2+}$-type complexes exhibit less favorable photophysical behavior as compared to $\left[\mathrm{Ru}(\mathrm{bpy})_{3}\right]^{2+}$ (shorter excited state lifetime and the absence of a room-

* Corresponding author. Phone: +31-30-2533120. Fax: +31-302523615. E-mail: g.vankoten@chem.uu.nl.

$\dagger$ Debye Institute, Department of Metal-Mediated Synthesis.

${ }^{\perp}$ Institute of Molecular Chemistry, Molecular Photonic Materials.

* Bijvoet Center for Biomolecular Research, Department of Crystal and Structural Chemistry.

$\S$ Corresponding author for crystallographic data. Phone: +31-302532538. Fax: +31-30-2523940. E-mail: a.l.spek@chem.uu.nl.

(1) (a) Sauvage, J.-P.; Collin, J.-P.; Chambron, J.-C.; Guillerez, S.; Coudret, C.; Balzani, V.; Barigelletti, F.; De Cola, L.; Flamigni, L. Chem. Rev. 1994, 94, 993. (b) Harriman, A.; Ziessel, R. Chem. Commun. 1996, 1707. (c) Constable, E. C. In Electronic Materials: The Oligomer Approach; Wiley: VCH: Weinheim, 1998. (d) Schwab, P. F. H.; Levin M. D.; Michl, J. Chem. Rev. 1999, 99, 1863. (e) Barigelletti, F. Flamigni, L. Chem. Soc. Rev. 2000, 29, 1. (f) Padilla-Tosta, M. E.; Lloris, J. M.; Martínez-Máñez, R.; Benito, A.; Soto, J.; Pardo, T.; Miranda, M. A.; Markos, M. D. Eur. J. Inorg. Chem. 2000, 741. (g) Constable, E. C.; Housecroft, C. E.; Johnston, L. A.; Armspach, D.; Neuburger, M.; Zehnder, M. Polyhedron 2001, 20, 483. (h) Maestri, M.; Armaroli, N.; Balzani, V.; Constable, E. C.; Cargill Thompson, A. M. W. Inorg. Chem. 1995, 34, 2759 .

(2) Juris, A.; Balzani, V.; Barigelletti, F.; Campagna, S.; Belser, P.; von Zelensky, A. Coord. Chem. Rev. 1998, 84, 85. temperature emission ${ }^{3}$ ), the higher symmetry of the resultant complexes is much more favorable. The tridentate coordination mode of terpyridine ligands results in high stereochemical control by avoiding the formation of isomeric mixtures present in tris-bidentate systems. ${ }^{4}$ Most recent work on the possible modification of the tridentate ligand has highlighted new strategies to improve the photophysical properties of the ruthenium(II) complex. Thus, the replacement of a nitrogen atom on a pyridine ring by a carbon atom considerably modifies the electronic properties of terpyridine-type ligands. ${ }^{5}$ The resulting anionic $\mathrm{C}, \mathrm{N}, \mathrm{N}$ or $\mathrm{N}, \mathrm{C}, \mathrm{N}$ chelating subunits, which lead to the formation of organometallic complexes containing a strong covalent metalcarbon bond, allow the MLCT state to be longer living and lead to luminescent ruthenium complexes at room temperature. ${ }^{5}$ In fact, these cyclometalating ligands cause a decrease in energy of the luminescent triplet metal to ligand charge transfer, ${ }^{3} \mathrm{MLCT}$. As a consequence, the energy gap between the emitting state and the nonradiative metal-centered ${ }^{3} \mathrm{MC}$ state, responsible for the quenching at room temperature of the emission in

(3) (a) Hissel, M.; El-Ghayoury, A.; Harriman, A.; Ziessel, R. Angew. Chem., Int. Ed. 1998, 37, 1717. (b) Winkler, J. R.; Netzel, T. L.; Crentz, C.; Sutin, N. J. Am. Chem. Soc. 1987, 109, 2381.

(4) (a) Sauvage, J.-P.; Ward, M. Inorg. Chem. 1991, 30, 3869. (b) von Zelensky, A. Stereochemistry of Coordination Compounds, Wiley: Chichester, 1996.

(5) (a) Padilla-Tosta, M. E.; Lloris, J. M.; Martínez-Máñez, Pardo, T.; Soto, J.; Benito, A.; Markos, M. D. Inorg. Chem. Commun. 2000, 3, 45. (b) Beley, M.; Collin, J.-P.; Sauvage, J.-P. Inorg. Chem. 1993, 32, 4539. (c) Collin, J.-P.; Gaviña, P.; Heitz, V.; Sauvage, J.-P Eur. J. Inorg. Chem. 1998, 1. 


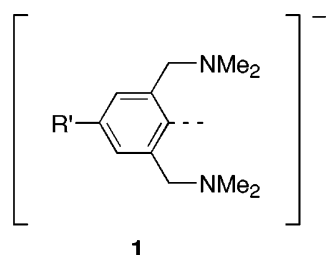

1

$\mathrm{R}^{\prime}=\mathrm{H}, \mathrm{Cl}, \mathrm{Br}, \mathrm{I}, \mathrm{Me}_{3} \mathrm{Si}, \mathrm{Me}_{3} \mathrm{SiC} \equiv \mathrm{C}, \mathrm{HC} \equiv \mathrm{C}$ $\mathrm{RO}$, alkyl, dendrimers, peptides, fullerenes

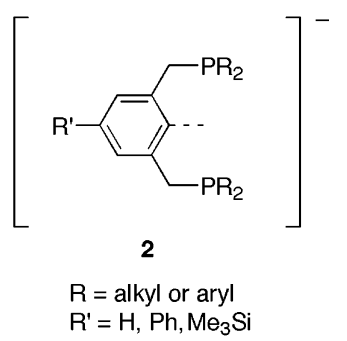

Figure 1. Monoanionic bisaminoaryl $\left[\mathrm{C}_{6} \mathrm{H}_{2}\left(\mathrm{CH}_{2} \mathrm{NMe}_{2}\right)_{2}-\right.$ 2,6-R'-4] $]^{-}(\mathbf{1})$ and bisphosphinoaryl $\left[\mathrm{C}_{6} \mathrm{H}_{2}\left(\mathrm{CH}_{2} \mathrm{PR}_{2}\right)_{2}-2,6\right.$ $\left.\mathrm{R}^{\prime}-4\right]^{-}(\mathbf{2})$ pincer ligands.

$\left[\mathrm{Ru}(\mathrm{tpy})_{2}\right]^{2+}$-type compounds, becomes so large that the emitting state can no longer be thermally populated.

The structural and chemical properties of $\mathrm{Ru}^{\mathrm{II}}$ complexes containing the terdentate coordinating monoanionic bisaminoaryl pincer ligands $\left[\mathrm{C}_{6} \mathrm{H}_{2}\left(\mathrm{CH}_{2} \mathrm{NMe}_{2}\right)_{2}-\right.$ 2,6-R'-4] ${ }^{-}$(NCN) (1, Figure 1) were widely investigated. ${ }^{6}$ The complexation of terpyridine ligands resulted in excellent stability of the $\mathrm{NCN}-\mathrm{Ru}^{\mathrm{II}}$ moieties and the concomitant use of $[\mathrm{Ru}(\mathrm{NCN})(\mathrm{tpy})] \mathrm{Cl}$ complexes as building blocks for dimeric architectures having potential optical and/or electronic applications. ${ }^{7} \mathrm{Ru}^{\mathrm{II}}$ complexes containing the related monoanionic $\eta^{3}-P, C, P$ coordinating bisphosphinoaryl ligands $\left[\mathrm{C}_{6} \mathrm{H}_{2}\left(\mathrm{CH}_{2} \mathrm{PR}_{2}\right)_{2^{-}}\right.$ 2,6-R'-4 $]^{-}(\mathbf{2}$, Figure 1$)$ have also received considerable attention. ${ }^{8}$ These complexes were used successfully as homogeneous catalysts in various metal-mediated organic transformations. ${ }^{8 \mathrm{~h}}$ However, despite the increasing interest in the influence of tertiary phosphines on the spectroscopic and redox properties of low-valent $\mathrm{Ru}^{\mathrm{II}}$ complexes, the lack of a convenient synthetic route to $[\mathrm{Ru}(\mathrm{PCP})(\mathrm{tpy})] \mathrm{Cl}$ complexes has considerably hampered their potential application as small devices specifically reacting to external stimuli.

In this paper, a facile route to synthesize $\mathrm{Ru}^{\mathrm{II}}$-tpy complexes containing PCP-pincer ligands is presented. In addition, it is shown how pincer ligand systems allow the tuning of the redox and photophysical properties of the chromophores prepared. The presence of soft donors (tertiary phosphines), together with hard donor nitrogen centers in the same complex, is useful to modulate the electronic properties of the metal centers and allows for additional use of ${ }^{31} \mathrm{P}$ NMR spectroscopy as an important characterization tool.

(6) (a) Sutter, J.-P.; James, S. L.; Steenwinkel, P.; Karlen, T.; Grove, D. M.; Veldman, N.; Smeets, W. J. J.; Spek, A. L.; van Koten, G. Organometallics 1996, 15, 941. (b) Steenwinkel, P.; James, S. L.; Grove, D. M.; Veldman, N.; Spek, A. L.; van Koten, G. Chem. Eur. J. 1996, 2, 1440 .

(7) Steenwinkel, P.; Grove, D. M.; Veldman, N.; Spek, A. L.; van Koten, G. Organometallics 1998, 17, 5647.

(8) (a) Karlen, T.; Dani, P.; Grove, D. M.; Steenwinkel, P.; van Koten, G. Organometallics 1996, 15, 5687. (b) Jia, G.; Lee, H. M.; Williams, I. D. J. Organomet. Chem. 1997, 534, 173. (c) Rybtchinski, B.; BenDavid, Y.; Milstein, D. Organometallics 1997, 16, 3786. (d) Jia, G.; Lau., C. P. J. Organomet. Chem. 1998, 565, 37. (e) Steenwinkel, P.; Kolmschot, S.; Gossage, R. A.; Dani, P.; Veldman, N.; Spek, A. L.; van Koten, G. Eur. J. Inorg. Chem. 1998, 477. (f) van der Boom, M. E.; Kraatz, H.-B.; Hassner, L.; Ben-David, Y.; Milstein, D. Organometallics 1999, 18, 3873. (g) Dani, P.; Albrecht, M.; van Klink, G. P. M.; van Koten, G. Organometallics 2000, 19, 4468. (h) Dani, P.; Karlen, T. Gossage, R. A.; Gladiali, S.; van Koten, G. Angew. Chem., Int. Ed. 2000 39, 743. (i) Dani, P.; van Klink, G. P. M.; van Koten G. Eur. J. Inorg. Chem. 2000, 1465. (j) Albrecht, M.; van Koten, G. Angew. Chem., Int. Ed. 2001, 40, 3750. (k) Dijkstra, H. P.; Albrecht, M.; Medici, S.; van Klink, G. P. M.; van Koten, G. Adv. Synth. Catal. 2002, 344, 1135. (1) Medici, S.; Gagliardo, M.; Williams, B. S.; Lutz, M.; Spek, A. L.; Gladiali, S.; van Klink, G. P. M.; van Koten, G. Submitted. (m) Singleton, J. T. Tetrahedron 2003, 59, 1873.
Scheme 1. Synthesis of $[\mathrm{Ru}(\mathrm{NCN})(\mathrm{tpy})] \mathrm{Cl}$ Complexes

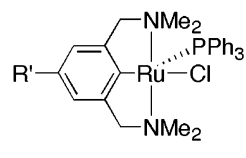

$\mathrm{R}^{\prime}=\mathrm{H}, \mathrm{Ph}, \mathrm{Me}_{3} \mathrm{Si}, \mathrm{Me}_{3} \mathrm{C} \equiv \mathrm{C}, \mathrm{HC} \equiv \mathrm{C}$

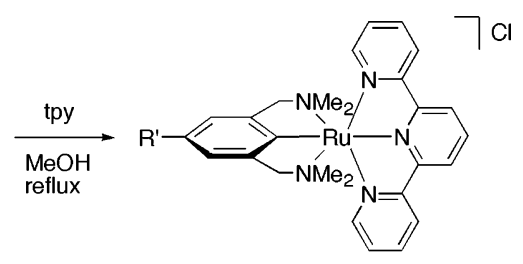

$R^{\prime}=H(3)$
Scheme 2. Synthesis of $[\operatorname{Ru}(\operatorname{PCP})(\mathrm{tpy})] \mathrm{Cl}$ Complexes via Direct Ruthenation of PCP-Pincer Ligands by $\left[\mathrm{RuCl}_{2}\left(\mathrm{PPh}_{3}\right)_{3}\right]$

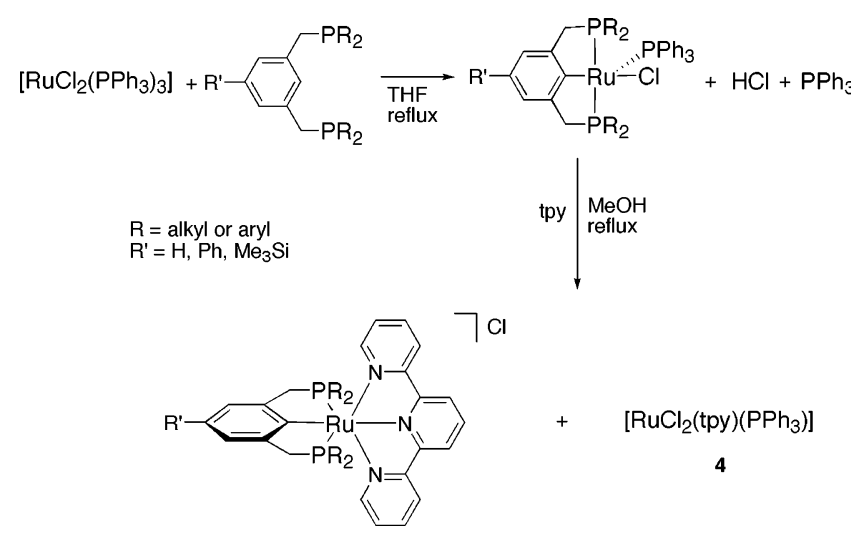

\section{Results and Discussion}

Synthesis of $\left[\mathbf{R u}^{\mathrm{II}}(\mathbf{P C P})(\mathrm{tpy})\right] \mathrm{X}(\mathrm{X}=\mathrm{Cl}$, OTf $)$ Complexes. In the course of our investigations directed toward the synthesis and reactivity of pincer-type arylruthenium(II) complexes containing the monoanionic terdentate coordinating bisaminoaryl $\left[\mathrm{C}_{6} \mathrm{H}_{2}\left(\mathrm{CH}_{2}\right.\right.$ $\left.\left.\mathrm{NMe}_{2}\right)_{2}-2,6-\mathrm{R}^{\prime}-4\right]^{-}(\mathrm{NCN})$ ligand, strategies for the preparation of new NCN-Ru ${ }^{\mathrm{II}}$ species containing the $2,2^{\prime}: 6^{\prime}, 2^{\prime \prime}$ terpyridine (tpy) ligand $([\mathrm{Ru}(\mathrm{NCN})($ tpy) $] \mathrm{Cl})$ were developed (Scheme 1). ${ }^{6}$ The results obtained using [Ru$(\mathrm{NCN})(\mathrm{tpy})] \mathrm{Cl}$ complexes for the preparation of new molecular systems that can be regarded as suitable components for the fabrication of optical devices ${ }^{7}$ prompted us to attempt the synthesis of analogous $\mathrm{Ru}^{\mathrm{II}}$ tpy compounds containing the monoanionic bisphosphinoaryl pincer ligand $\left[\mathrm{C}_{6} \mathrm{H}_{3}\left(\mathrm{CH}_{2} \mathrm{PR}_{2}\right)_{2}-2,6\right]^{-}(\mathrm{PCP})(\mathbf{2}$, Figure 1). ${ }^{9}$ The common synthetic pathway, which involves reaction of $\left[\mathrm{RuCl}\left\{\mathrm{C}_{6} \mathrm{H}_{3}\left(\mathrm{CH}_{2} \mathrm{PR}_{2}\right)_{2}-2,6\right\}\left(\mathrm{PPh}_{3}\right)\right]$ $(\mathrm{R}=\mathrm{Ph}(\mathbf{9}) ; i \operatorname{Pr}(\mathbf{1 0})$, vide infra Scheme 3$)$ and tpy in $\mathrm{MeOH}$ at room temperature, gave the desired compounds unfortunately only in low yield. ${ }^{8 a}$ Although $\left[\mathrm{RuCl}(\mathrm{NCN})\left(\mathrm{PPh}_{3}\right)\right]$ and $\left[\mathrm{RuCl}(\mathrm{PCP})\left(\mathrm{PPh}_{3}\right)\right]$ complexes are structurally closely related, ${ }^{6 a, 8 b}$ the observed decrease in the overall yield for the reaction with tpy reflects changes in the electronic and steric properties operative at and around the metal center. Additionally, the concomitant formation of $\left[\mathrm{RuCl}_{2}(\mathrm{tpy})\left(\mathrm{PPh}_{3}\right)\right]$ (4) (Scheme 2) proved to be a major inhibiting factor for selective and quantitative synthesis of $[\mathrm{Ru}(\mathrm{PCP})(\mathrm{tpy})]-$ $\mathrm{Cl}$ complexes. This limitation was ascribed to the nature of $\left[\mathrm{RuCl}(\mathrm{PCP})\left(\mathrm{PPh}_{3}\right)\right]$ prepared via direct cyclometalation of meta-bisphosphinoarene ligand (Figure 1) with $\left[\mathrm{RuCl}_{2}\left(\mathrm{PPh}_{3}\right)_{3}\right]$ used as starting material (Scheme 2). ${ }^{8 \mathrm{a}, \mathrm{g}}$

(9) Karlen, T.; Dani, P.; Grove, D. M.; Steenwinkel, P.; van Koten G. Organometallics 1996, 15, 5687. 
Table 1. Selected Bond Lengths (̊̊), Bond Angles (deg), and Torsion Angles (deg) for the First Independent Molecule of Complex 4 (values for the second independent molecule are given in square brackets)

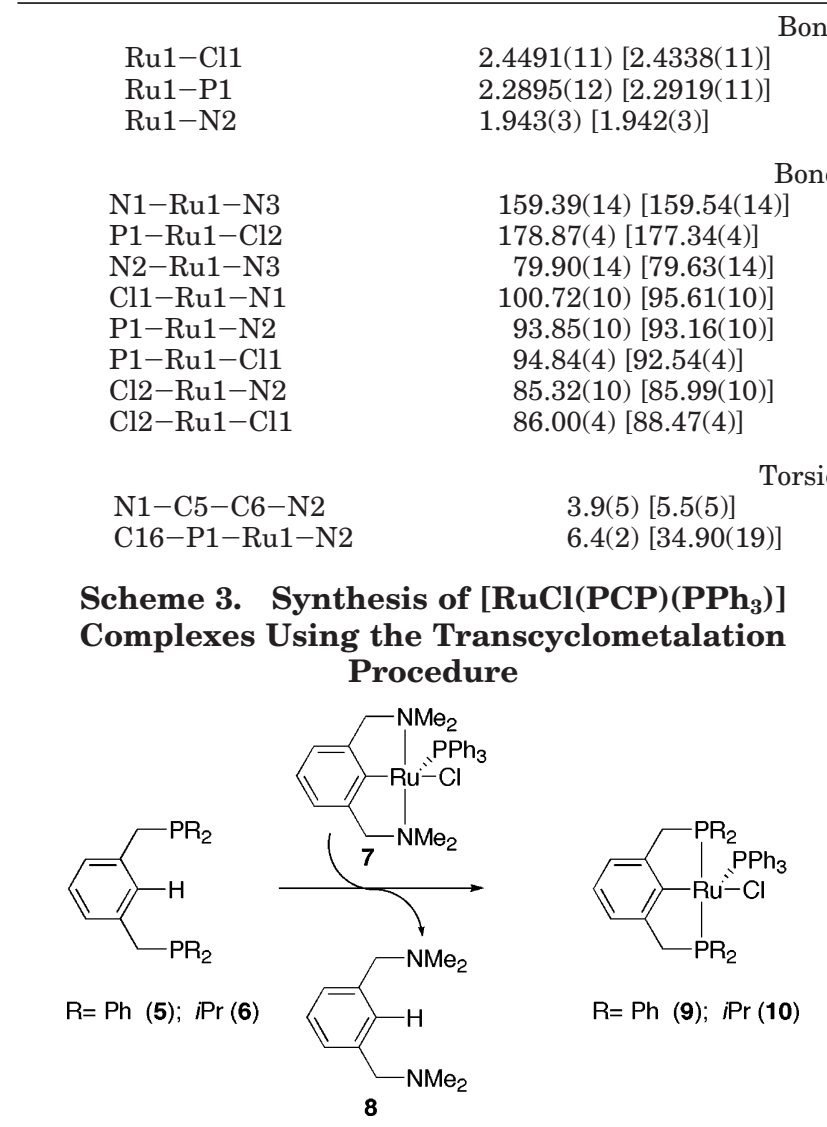

Unidentified oligomeric $\mathrm{PCPRu}{ }^{\mathrm{II}}$ species, present as impurities in the prepared $\left[\mathrm{RuCl}(\mathrm{PCP})\left(\mathrm{PPh}_{3}\right)\right]$ complexes, ${ }^{9}$ coordinate in refluxing $\mathrm{MeOH}$ with tpy, giving the octahedral $18 \mathrm{e} \mathrm{Ru}{ }^{\mathrm{II}}$ complex 4 in approximately $20 \%$ yield. Unfortunately, attempts to purify the desired $[\mathrm{Ru}(\mathrm{PCP})(\mathrm{tpy})] \mathrm{Cl}$ complexes from 4 failed. The presence of 4 can be easily confirmed by ${ }^{1} \mathrm{H}$ and ${ }^{31} \mathrm{P}$ NMR spectroscopy. The ${ }^{31} \mathrm{P}$ NMR spectrum is particularly useful to identify complex 4 from a singlet at $21.5 \mathrm{ppm}$ in $\mathrm{CD}_{2} \mathrm{Cl}_{2}$, which is indicative of the $\mathrm{PPh}_{3}$ coordinated to the ruthenium metal center. The molecular structure of complex 4 (Figure 2; bond lengths, angles, and torsion angles in Table 1) has been characterized by X-ray diffraction analysis of single crystals grown by slow diffusion of $\mathrm{Et}_{2} \mathrm{O}$ vapor in a $\mathrm{CH}_{2} \mathrm{Cl}_{2}$ solution containing both complexes 4 and $\mathbf{1 1}$.

To overcome the above-mentioned limitations, a new synthetic approach for the preparation of $[\mathrm{RuCl}(\mathrm{PCP})$ $\left.\left(\mathrm{PPh}_{3}\right)\right]$ compounds ${ }^{8 \mathrm{~g}}$ was developed. This alternative synthetic route employs the transcyclometalation (TCM) reaction (Scheme 3), which represents an elegant methodology for the formation of a metal-carbon bond under relatively mild conditions and proceeds selectively and in quantitative yield. The reaction pathway (Scheme 3), similar to an electrophilic aromatic substitution reaction, involves the formal exchange of a terdentate coordinated monoanionic bisaminoaryl ligand, $\left[\mathrm{C}_{6} \mathrm{H}_{3}\left(\mathrm{CH}_{2}-\right.\right.$ $\left.\left.\mathrm{NMe}_{2}\right)_{2}-2,6\right]^{-}$, in complex $\left[\mathrm{RuCl}\left\{\mathrm{C}_{6} \mathrm{H}_{3}\left(\mathrm{CH}_{2} \mathrm{NMe}_{2}\right)_{2}-2,6\right\}-\right.$ $\left.\left(\mathrm{PPh}_{3}\right)\right](\mathbf{7})$ by a corresponding terdentate coordinated bisphosphinoaryl ligand $\left[\mathrm{C}_{6} \mathrm{H}_{3}\left(\mathrm{CH}_{2} \mathrm{PR}_{2}\right)_{2}-2,6\right]^{-}$, leading to the formation of $\left[\mathrm{RuCl}(\mathrm{PCP})\left(\mathrm{PPh}_{3}\right)\right]$ complexes. The only coproduct is the bisaminoarene $\mathbf{8}$, which is highly
Ru1-Cl2
Ru1-N1
Ru1-N3

$\mathrm{N} 2-\mathrm{Ru} 1-\mathrm{Cl} 1$

$\mathrm{N} 1-\mathrm{Ru} 1-\mathrm{N} 2$

N3-Ru1-Cl1

$\mathrm{P} 1-\mathrm{Ru} 1-\mathrm{N} 1$

$\mathrm{P} 1-\mathrm{Ru} 1-\mathrm{N} 3$

$\mathrm{Cl} 2-\mathrm{Ru} 1-\mathrm{N} 1$

$\mathrm{Cl} 2-\mathrm{Ru} 1-\mathrm{N} 3$

\author{
$2.4545(11)[2.4679(11)]$ \\ $2.073(3)[2.052(3)]$ \\ $2.072(3)[2.070(3)]$
}

171.27(10) [173.36(10)]

79.63(14) [80.59(14)]

99.16(10) [103.55(10)]

93.15(10) [94.12(9)]

$90.59(10)[92.15(9)]$

85.96(9) [88.23(9)]

90.01(10) [85.22(9)]

$$
\mathrm{N} 2-\mathrm{C} 10-\mathrm{C} 11-\mathrm{N} 3 \quad-6.7(5)[-3.9(5)]
$$

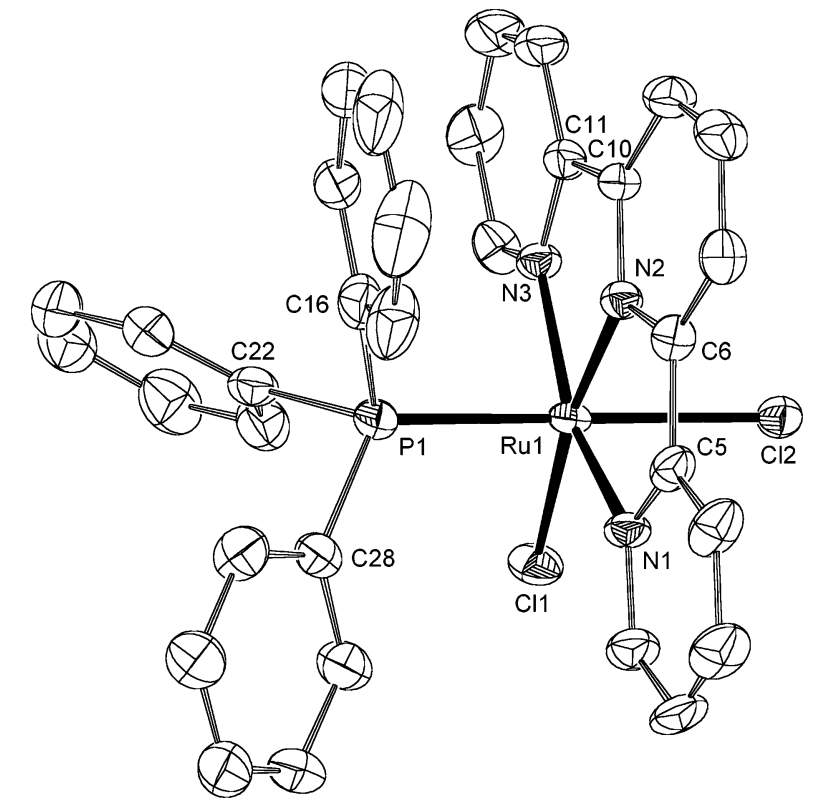

Figure 2. Displacement ellipsoid plot (50\% probability level) of 4. Only the first of two independent molecules is shown. Hydrogen atoms and solvent molecules have been omitted for clarity.

soluble in apolar solvents and allows for simple separation from the desired product. Furthermore, the formation of secondary products is suppressed as chlorinated solvents are not used, and thus $\mathrm{HCl}$ cannot be generated during the reaction. Recent results demonstrated that the TCM reaction is also superior over established metalation procedures if several ruthenium metal centers are to be introduced in shape-persistent macromolecular multi(pincer) ligands. ${ }^{10}$

The synthesis of complexes $\mathbf{9}$ and $\mathbf{1 0}$ (Scheme 3) was performed using the TCM methodology by reaction of a 1:1 molar mixture of ligands 5 and $\mathbf{6}$, respectively, with 7 in refluxing $\mathrm{C}_{6} \mathrm{H}_{6}$ (Scheme 3). ${ }^{8 g, \mathrm{k}}$ The resultant complexes $\mathbf{9}$ and $\mathbf{1 0}$ were isolated pure as green, airsensitive solids in good yields. Spectroscopic characterization confirmed that both complexes $\mathbf{9}$ and $\mathbf{1 0}$ have square pyramidal geometries with the $\mathrm{PPh}_{3}$ ligand occupying the apical position. ${ }^{8 b, f, i}$ As shown in Scheme

(10) Dijkstra, H. P.; Albrecht, M.; van Koten, G. Chem. Commun. 2002, 126. 
Scheme 4. Synthesis of $[R u(P C P)(t p y)] C l$ Complexes

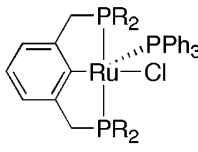

$\mathrm{R}=\mathrm{Ph}(\mathbf{9}) ; \operatorname{Pr}(\mathbf{1 0})$

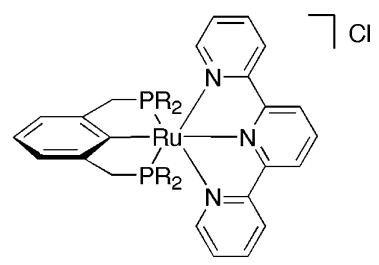

$\mathrm{R}=\operatorname{Ph}(\mathbf{1 1}) ; \operatorname{Pr}(\mathbf{1 2})$
Scheme 5. Synthesis of $[R u(P C P)(t p y)]($ OTf $)$ Complex 14 by Method (a) (top) and Method (b) (bottom)

Method (a)
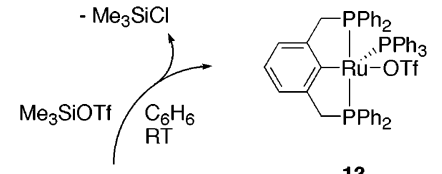

13
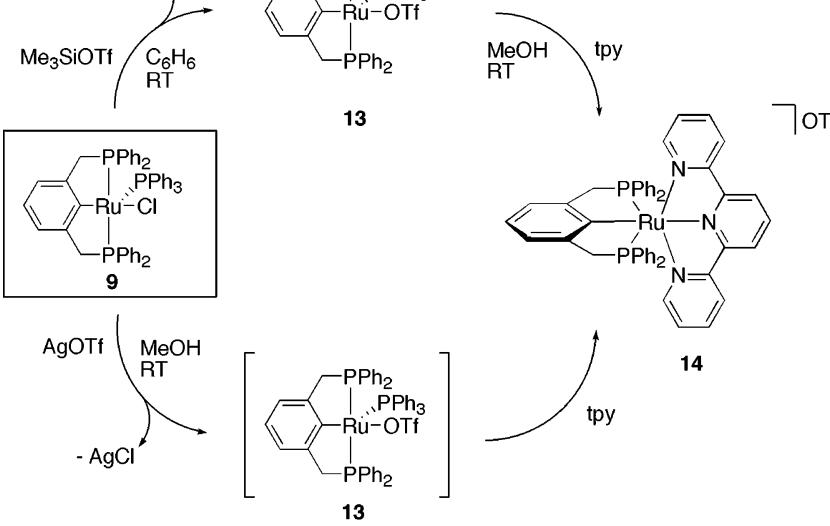

Method (b)

4, $[\mathrm{Ru}(\mathrm{PCP})($ tpy $)] \mathrm{Cl}$ complexes $\mathbf{1 1}$ and $\mathbf{1 2}$ are readily prepared in high yield ( 86 and $84 \%$, respectively) by reaction of $\left[\mathrm{RuCl}(\mathrm{PCP})\left(\mathrm{PPh}_{3}\right)\right]$ complexes 9 and 10, respectively, with tpy in dry $\mathrm{MeOH}$ at reflux temperature. ${ }^{9}$ The red complexes $\mathbf{1 1}$ and $\mathbf{1 2}$ are soluble in apolar solvents and alcohols, such as methanol and ethanol, and were fully characterized by NMR spectroscopy in $\mathrm{CD}_{2} \mathrm{Cl}_{2}$ and elemental analysis. Because of the long reaction times (3 days at reflux), other preparative procedures were examined in order to obtain the desired complexes faster and with comparable selectivity. The low reactivity of $\left[\mathrm{RuCl}(\mathrm{PCP})\left(\mathrm{PPh}_{3}\right)\right]$ complexes toward tpy is partly due to their sparingly solubility nature in methanol. In addition, the ability of the chloride anion to act as leaving group in complex $\mathbf{9}$ proved to be a fundamental and crucial step for the rapid and selective formation of desired $[\mathrm{Ru}(\mathrm{PCP})(\mathrm{tpy})] \mathrm{Cl}$ complexes. Two halide-abstracting strategies were investigated for replacing the chloride for a better leaving group such as the trifluoromethanesulfonate anion (triflate, OTf, $\mathrm{F}_{3} \mathrm{CSO}_{3}{ }^{-}$). The first method involved the reaction of a solution of complex 9 in benzene with an excess of $\mathrm{Me}_{3} \mathrm{SiOTf}$ at room temperature for $1 \mathrm{~h}$, to afford the corresponding triflate complex 13 (Scheme 5). After removal of the solvent and $\mathrm{Me}_{3} \mathrm{SiCl}$ (a volatile liquid) and washing out of the residual $\mathrm{Me}_{3} \mathrm{SiOTf}$ (highly soluble in apolar solvents), an equimolar solution of tpy in methanol was added to the resultant green solid residue. The reaction mixture was stirred at room temperature for $3 \mathrm{~h}$, yielding after workup $\left[\mathrm{Ru}\left\{\mathrm{C}_{6} \mathrm{H}_{3}-\right.\right.$
$\left.\left(\mathrm{CH}_{2} \mathrm{PPh}_{2}\right)_{2}-2,6\right\}$ (tpy)](OTf) (14) as a red solid in good yield $(90 \%)$.

In the second and even faster and more convenient one-pot synthesis, the chloride was replaced in situ in dry $\mathrm{MeOH}$ with a stoichiometric amount of AgOTf in the presence of tpy. After stirring at room temperature for $3 \mathrm{~h}$ the reaction was complete and the silver chloride was removed by filtration. After workup of the methanolic solution, $\left[\mathrm{Ru}\left\{\mathrm{C}_{6} \mathrm{H}_{3}\left(\mathrm{CH}_{2} \mathrm{PPh}_{2}\right)_{2}-2,6\right\}\right.$ (tpy)](OTf) (14) was obtained pure in $86 \%$ yield as a red air-stable powder. The same synthetic procedure applied under reflux conditions did not accelerate the reaction but showed, surprisingly, the concomitant formation (10\%) of an $\mathrm{Ag}^{\mathrm{I}}$ (tpy) complex $\left(\left[\mathrm{Ag}^{\mathrm{I}}(\mathrm{tpy})\left(\mathrm{PPh}_{3}\right)\right] \mathrm{OTf}\right)$, which was characterized by single-crystal X-ray diffraction. ${ }^{11}$

Crystal Structure of $\left[\mathrm{RuCl}_{2}(\mathrm{tpy})\left(\mathrm{PPh}_{3}\right)\right](4)$ and $\left[\mathbf{R u}\left\{\mathrm{C}_{6} \mathrm{H}_{3}\left(\mathrm{CH}_{2} \mathrm{PPh}_{2}\right)_{2}\right.\right.$-2,6\}(tpy)](OTf) (14). The crystal structure of the $\mathrm{Et}_{2} \mathrm{O} / \mathrm{CH}_{2} \mathrm{Cl}_{2}$ solvate of 4 contains two crystallographically independent $\mathrm{Ru}^{\mathrm{II}}$ complexes, which mainly differ in the orientation of the $\mathrm{PPh}_{3}$ ligand. In the first molecule, the $\mathrm{PPh}_{3}$ group is eclipsed with $\mathrm{N} 2$ of the tpy ligand $\left(\mathrm{C} 16-\mathrm{P} 1-\mathrm{Ru} 1-\mathrm{N} 2=6.4(2)^{\circ}\right)$, while in the second molecule the $\mathrm{PPh}_{3}$ ligand is staggered $\left(\mathrm{C} 16-\mathrm{P} 1-\mathrm{Ru} 1-\mathrm{N} 2=34.90(19)^{\circ}\right)$. A molecular plot of the first independent molecule is depicted in Figure 2. A selection of bond lengths, angles, and torsion angles of $\mathbf{4}$ is summarized in Table 1.

The $\mathrm{Ru}^{\mathrm{II}}$ center is in a severely distorted octahedral environment coordinated to a tridentate tpy ligand, one $\mathrm{PPh}_{3}$ ligand, and two chloride anions in a mutual cisarrangement. The distortion is reflected in the octahedral angle variance ${ }^{12}$ of $46.46^{\circ}\left(44.87^{\circ}\right.$ for the second molecule) compared to $0.0^{\circ}$ for an ideal octahedron. The reason for this distortion is the strain generated by the chelating $\eta^{3}$-tpy ligand. This strain can also be seen in the $\mathrm{Ru}-\mathrm{N}$ distances, which are significantly shorter for the central N2 (1.943(3) and 1.942(3) $\AA$ for the $\mathrm{PPh}_{3}$ eclipsed and staggered, respectively) than for the terminal N1 and N3 atoms $(2.052(3)-2.073(3) \AA)$. Similar differences can also be found in the literature. ${ }^{13}$ The $\mathrm{Ru}-\mathrm{Cl} 1$ distances $(2.4491(11)$ and 2.4338(11) $\AA$ ), which are trans to N2 of the tpy ligand, are slightly shorter than the $\mathrm{Ru}-\mathrm{Cl} 2$ distances $(2.4545(11)$ and $2.4679(11)$ $\AA$ ), which are trans to the $\mathrm{PPh}_{3}$ ligand. As expected for a $\mathrm{Ru}^{\mathrm{II}}$ complex, the tpy ligand is essentially planar and the metal is situated in this plane.

Single crystals of 14 suitable for X-ray crystallography were grown from a $\mathrm{CH}_{2} \mathrm{Cl}_{2}$ solution into which diethyl ether vapor was allowed to diffuse slowly. Figure 3 depicts the molecular structure of $\mathbf{1 4}$ (a selection of bond lengths, angles, and torsion angles of $\mathbf{1 4}$ is summarized in Table 2). In the molecular structure of 14, the ruthenium center is in a distorted octahedral geometry with both the tpy and the bis(ortho-)chelating PCP ligands coordinated meridionally. The distortion of the octahedron, with an angle variance of $102.71^{\circ}$, is even larger than in the two independent molecules of com-

(11) Lutz, M.; Spek, A. L.; Gagliardo, M.; van Klink, G. P. M.; van Koten, G. To be submitted.

(12) Robinson, K.; Gibbs, G. V.; Ribbe P. H. Science 1971, 172, 567.

(13) (a) Beley, M.; Collin, J.-P.; Louis, R.; Metz, B.; Sauvage, J.-P J. Am. Chem. Soc. 1991, 113, 8521. (b) Constable, E. C.; Cargill Thompson, A. M. W. New J. Chem. 1992, 16, 855. (c) Encinas, S.; Flamigni, L.; Barigelletti, F.; Constable, E. C.; Housecroft, C. E.; Schofield, E. R.; Figgemeier, E.; Fenske, D.; Neuburger, M.; Vos, J. G.; Zehnder, M. Chem. Eur. J. 2002, 8, 137. 


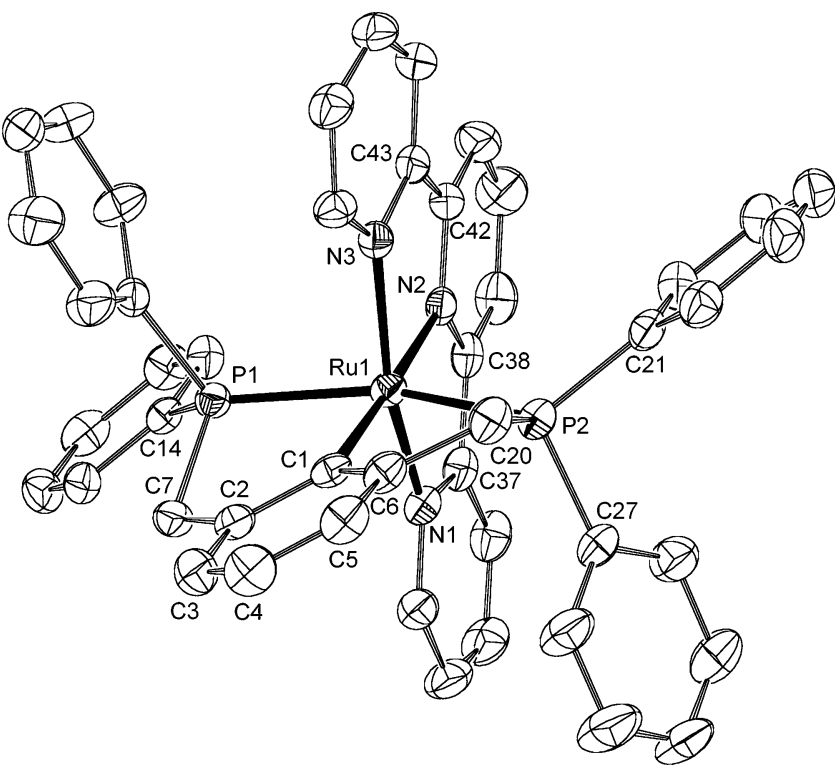

Figure 3. Displacement ellipsoid plot (50\% probability level) of the cationic portion of 14. Hydrogen atoms, the triflate anion, and solvent molecules have been omitted for clarity.

Table 2. Selected Bond Lengths (Å), Bond Angles (deg), and Torsion Angles (deg) for 14

\begin{tabular}{lrlr}
\multicolumn{5}{c}{ Bond Lengths $(\AA)$} \\
Ru1-N1 & $2.083(2)$ & Ru1-N2 & $2.0090(19)$ \\
Ru1-N3 & $2.078(2)$ & Ru1-C1 & $2.108(2)$ \\
Ru1-P1 & $2.3241(7)$ & Ru1-P2 & $2.3094(7)$ \\
\multicolumn{5}{c}{ Bond Angles (deg) } \\
N1-Ru1-N3 & $157.29(8)$ & N2-Ru1-C1 & $177.15(9)$ \\
P1-Ru1-P2 & $156.09(2)$ & N1-Ru1-N2 & $78.55(8)$ \\
N2-Ru1-N3 & $78.74(8)$ & N3-Ru1-C1 & $98.44(9)$ \\
C1-Ru1-N1 & $104.27(9)$ & P1-Ru1-N1 & $91.20(6)$ \\
P1-Ru1-N2 & $101.28(5)$ & P1-Ru1-N3 & $93.24(6)$ \\
P1-Ru1-C1 & $78.41(7)$ & P2-Ru1-N1 & $93.30(6)$ \\
P2-Ru1-N2 & $102.63(6)$ & P2-Ru1-N3 & $91.61(6)$ \\
P2-Ru1-C1 & $77.73(7)$ & & \\
\multicolumn{5}{c}{ Torsion Angles (deg) } \\
N1-C37-C38-N2 & $4.0(3)$ & N2-C42-C43-N3 \\
C1-C2-C7-P1 & $-26.3(3)$ & C1-C6-C20-P2 & $-23.5(3)$ \\
\multicolumn{5}{c}{ - $23(3)$}
\end{tabular}

pound 4. In addition to the steric strain of the tpy ligand, which is also present in $\mathbf{4}$, there is the steric strain imposed by the PCP-pincer ligand, leading to a considerable distortion of the complex. The $\mathrm{P} 1-\mathrm{Ru} 1-\mathrm{P} 2$ bond angle is $156.09(2)^{\circ}$, which is significantly less than linear. The resulting $\mathrm{C}_{\mathrm{aryl}}-\mathrm{Ru}-\mathrm{P}$ bite angles of the bis(ortho-)chelating PCP ligand, $\mathrm{C} 1-\mathrm{Ru} 1-\mathrm{P} 1$ and $\mathrm{C} 1-$ Ru1-P2, are $78.41(7)^{\circ}$ and $77.73(7)^{\circ}$, respectively. The strain of the PCP-pincer ligand can also be seen in the $\mathrm{Ru}-\mathrm{P}$ distances, which are significantly different (2.3094(7) and 2.3241(7) $\AA$ ). The terdentate coordination of the PCP-pincer ligand affords a Ru1-C1 bond of 2.108(2) $\AA$, significantly longer than the $\mathrm{Ru} 1-\mathrm{C} 1$ bond in the analogous complex $[\mathrm{Ru}(\mathrm{NCN})(\mathrm{tpy})] \mathrm{Cl}(\mathbf{3})(\mathrm{Ru} 1-\mathrm{C} 1=$ $1.982(7) \AA)^{6 a}$ However, this value falls in the range of reported values for other $\mathrm{PCP}-\mathrm{Ru}^{\mathrm{II}}$ complexes. ${ }^{8 \mathrm{~b}, \mathrm{f}}$

The $\mathrm{Ru}-\mathrm{N}$ bonds lengths $(\mathrm{Ru} 1-\mathrm{N} 1=2.083(2) \AA$; $\mathrm{Ru} 1-\mathrm{N} 2=2.0090(19) \AA ;$ Ru1-N3 = 2.078(2) $\AA$ ) are similar to those found for other $\mathrm{Ru}^{\mathrm{II}}$ complexes containing terdentate tpy ligands. ${ }^{\mathrm{Ig}, 13}$ As observed for other $\mathrm{Ru}^{\mathrm{II}}$ complexes containing tpy ligands, the $\mathrm{Ru}-\mathrm{N}$ contacts to the central ring of the tpy ligand are shorter than those to the terminal rings. The tpy ligand is ap-

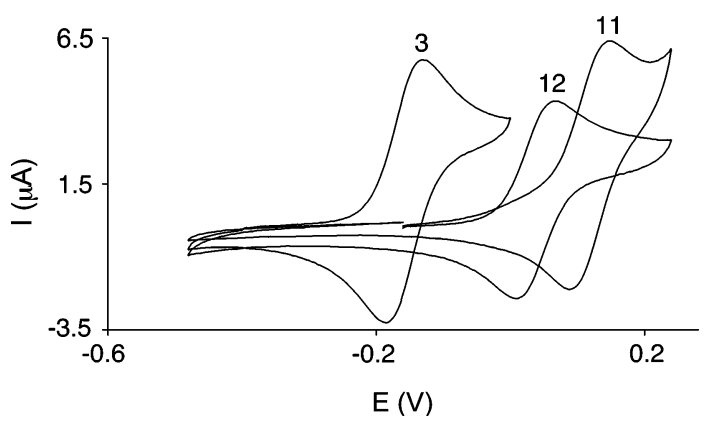

Figure 4. Cyclic voltammograms of complexes $3(\mathrm{NCN})$, $11(\mathrm{PCP}-\mathrm{Ph})$, and $12(\mathrm{PCP}-i \mathrm{Pr})$ measured in butyronitrile at $298 \mathrm{~K}\left(0.1 \mathrm{M} \mathrm{TBAH}\right.$; scan rate $\left.=100 \mathrm{mV} \mathrm{s}^{-1}\right)$.

Table 3. Absorption and Electrochemical Data of 3,11 , and 12

\begin{tabular}{lccc}
\hline $\begin{array}{c}\text { complex } \\
\text { (ligand) }\end{array}$ & $\begin{array}{c}\lambda_{\max }(\mathrm{nm})^{a} \\
\epsilon_{\max }\left(\mathrm{M}^{-1} \mathrm{~cm}^{-1}\right)\end{array}$ & $\begin{array}{c}E_{1 / 2}(\mathrm{ox})(\mathrm{V})^{b} \\
\mathrm{Ru}^{\mathrm{II}} / \mathrm{Ru}^{\mathrm{III}}\end{array}$ & $\begin{array}{c}E_{1 / 2}(\mathrm{red})(\mathrm{V})^{b} \\
\text { tpy/tpy }^{-}\end{array}$ \\
\hline $\mathbf{3}(\mathrm{NCN})$ & $524(65800)$ & -0.178 & -2.031 \\
$\mathbf{1 1}(\mathrm{PCP}-\mathrm{Ph})$ & $479(43850)$ & 0.167 & -1.946 \\
$\mathbf{1 2}(\mathrm{PCP}-i \mathrm{Pr})$ & $513(41350)$ & 0.056 & -1.978
\end{tabular}

${ }^{a}$ Absorption maxima relative to ${ }^{1} \mathrm{MLCT}$ transitions. Measured at $298 \mathrm{~K}$ in $\mathrm{CH}_{3} \mathrm{CN}$. ${ }^{b}$ Measured at $298 \mathrm{~K}$ in butyronitrile solutions containing $0.1 \mathrm{M}$ TBAH. Potentials in $\mathrm{V}$ reported vs $\mathrm{Fc} / \mathrm{Fc}^{+}$.

proximately planar, with torsion angles between the terminal rings and the directly bonded rings being $4.0(3)^{\circ}$ and $-3.5(3)^{\circ}$.

The ligand arrangement of $[\mathrm{Ru}(\mathrm{PCP})(\mathrm{tpy})] \mathrm{Cl}$ complexes observed in the molecular structure of complex 14 is preserved in solution. The ${ }^{1} \mathrm{H}$ NMR spectrum of 14, recorded at room temperature in $\mathrm{CD}_{2} \mathrm{Cl}_{2}$, shows a single resonance for the benzylic hydrogens, indicative of a molecular mirror plane containing the benzylic carbon atoms. In the ${ }^{31} \mathrm{P}$ NMR spectra only one singlet resonance for the phosphorus nuclei is observed. Since the NMR data of complexes 11 and $\mathbf{1 2}$ show similar patterns, it can be deduced that their molecular structures are analogous to the structure of complex 14.

Electrochemical and Photophysical Properties of Complexes 3, 11, and 12. The presence of hard and soft donor centers in the NCN- and PCP-pincer ligand systems, respectively, results in tunable and interesting electrochemical and spectroscopic behavior of the prepared complexes $[\mathrm{Ru}(\mathrm{NCN})(\mathrm{tpy})] \mathrm{Cl}(\mathbf{3})$ and $[\mathrm{Ru}(\mathrm{PCP})-$ (tpy)]Cl (11 and 12).

The anodic region of the cyclic voltammogram of complexes 3, 11, and $\mathbf{1 2}$ (Figure 4) is dominated by a reversible wave corresponding to one-electron oxidation of the $\mathrm{Ru}^{\mathrm{II}}$ state, while the cathodic regions exhibit defined reversible waves related to the reduction of the coordinated tpy ligand. The measured $E_{1 / 2}$ values versus the couple $\mathrm{Fc} / \mathrm{Fc}^{+}$for all three compounds are reported in Table 3 . The oxidation potentials of $[\mathrm{Ru}(\mathrm{NCN})(\mathrm{tpy})]$ $\mathrm{Cl}$ and $[\mathrm{Ru}(\mathrm{PCP})($ tpy) $)] \mathrm{Cl}$ complexes are significantly lower than that of $\left[\mathrm{Ru}(\mathrm{tpy})_{2}\right]\left(\mathrm{PF}_{6}\right)_{2}\left(0.92 \mathrm{~V} \mathrm{vs} \mathrm{Fc} / \mathrm{Fc}^{+}\right)^{1 \mathrm{a}}$. This indicates that the $\sigma$-donor capability of the monomeric NCN- and PCP-pincer ligands is much stronger than that of tpy. ${ }^{13 b, 14}$ The electron donation ability of the coordinated ligands, which results in an easier oxidation of the ruthenium ion, is reflected in the

(14) (a) Beley, M.; Collin, J.-P.; Sauvage, J.-P. Inorg. Chem. 1993, 32, 4539. (b) Bardwell, D.; Cargill Thompson, A. M. W.; Jeffery, J. C.; McCleverty, J. A.; Ward, M. D. J. Chem. Soc., Dalton Trans 1996, 873 (c) Koizumi, T.; Tomon, T.; Tanaka, K. Organometallics 2003, 22, 970. 


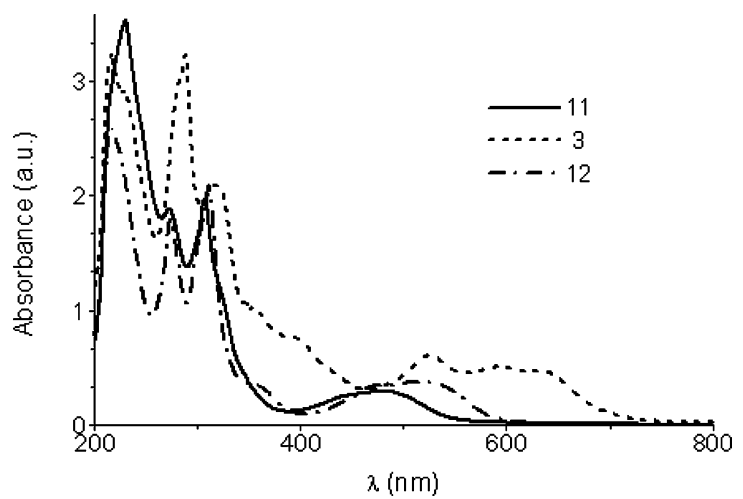

Figure 5. UV-vis absorption spectra of complexes 3 (NCN), 11 (PCP-Ph), and 12 (PCP- $i \mathrm{Pr})$ measured in $\mathrm{CH}_{3-}$ $\mathrm{CN}$ at $298 \mathrm{~K}$.

oxidation potentials for complexes $\mathbf{3}, \mathbf{1 1}$, and 12. ${ }^{14}$ The $\mathrm{Ru}^{\mathrm{II}} / \mathrm{Ru}^{\mathrm{III}}$ redox potentials of complexes $\mathbf{1 1}$ and $\mathbf{1 2}$ $\left(E_{1 / 2}=0.167\right.$ and $0.056 \mathrm{~V}$ vs $\mathrm{Fc} / \mathrm{Fc}^{+}$, respectively) are more positive than that of complex $3\left(E_{1 / 2}=-0.178 \mathrm{~V}\right.$ vs $\mathrm{Fc} / \mathrm{Fc}^{+}$) by approximately $0.3 \mathrm{~V}$. The observed increase in the oxidation potential is a sign of the softer $\sigma$-donor properties combined with the back-donation of the PCP-pincer ligands compared to NCN-pincer ligands. However, the $\sigma$ electron-donating and $\pi$ withdrawing properties of PCP-pincer ligands can be easily modulated by varying the substituents on the phosphorus atoms. The presence of more donating groups, such as $i$ Pr, increases the stability of the $\mathrm{Ru}^{\mathrm{III}}$ species, resulting in a lower redox potential of complex 12 compared to 11. The influence of the NCN- and PCP-pincer ligands is reflected in different reactivity of $[\mathrm{Ru}(\mathrm{NCN})(\mathrm{tpy})] \mathrm{Cl}$ complexes toward oxidants as compared to [Ru(PCP)(tpy)]Cl complexes. ${ }^{15}$

The absorption spectra of $\mathbf{3}, \mathbf{1 1}$, and 12, measured in $\mathrm{CH}_{3} \mathrm{CN}$ at room temperature (Figure 5), show features that can be easily interpreted by comparison with literature data. ${ }^{1,6 a}$ Table 3 shows the absorption maxima, $\lambda_{\max }$, and the molar extinction coefficient, $\epsilon_{\max }$, values for all the complexes in their +2 oxidation state. The spectra exhibit intense spin-allowed ligand-centered (LC) $\pi \rightarrow \pi^{*}$ transitions in the UV region and broad spin-allowed $\mathrm{d}(\pi) \rightarrow \pi^{*}$ metal-to-ligand charge transfer (MLCT) absorption bands in the visible region. The terpyridine $\pi \rightarrow \pi^{*}$ absorptions are the same for all the complexes and are centered at about $310 \mathrm{~nm}$. The PCP and NCN ligands are electronically quite different, and their transitions occur at 270 and $280 \mathrm{~nm}$, respectively. It is interesting to note that due to the heteroleptic nature of the complexes, the lowest MLCT excited state could involve either the terpyridine or the cyclometalated ligand. It is clear that in our systems the lowest excited state involves the terpyridine ligand since the strong electron-donating character for the NCN and to a lesser extent for the PCP ligand shifts the Ru $\rightarrow$ tpy transition to lower energy. In fact a more accurate analysis of the absorption spectra reveals more than one absorption band between 450 and $600 \mathrm{~nm}$, particularly evident in the NCN complex 3, with the lowest transition involving the tpy ligand. Furthermore substitution of the NCN-pincer ligand by PCP-pincer ligands results

(15) Gagliardo, M.; Amijs, C. H.; Lutz, M.; Spek, A. L.; van Klink, G. P. M.; van Koten, G. To be submitted. in ipsochromic shifts of the MLCT bands for complexes 11 and 12. Also the MLCT transitions for $\mathbf{1 1}$ and $\mathbf{1 2}$ are slightly different since the substituents on the coordinating phosphorus atoms, $i \mathrm{Pr}$ and $\mathrm{Ph}$, have different electronic properties, which influence the electron density on the metal ion. These results are in good agreement with the more positive $\mathrm{Ru}{ }^{\mathrm{II}} / \mathrm{Ru}^{\mathrm{III}}$ redox potential values observed in the cyclic voltammetry studies, and a relationship between electrochemical redox potentials and the energy of the absorption maxima may be found. Assuming that the $\pi\left(t_{2 g}\right)$ metal orbital and the $\pi^{*}$ orbital, involved in the first oxidation and in the first reduction processes, respectively, are also the orbitals involved in the MLCT absorption process, a linear correlation between the absorption maximum energy with increasing $\Delta E_{1 / 2}\left(=e\left[E_{1 / 2}(\right.\right.$ ox $)-$ $E_{1 / 2}($ red)] $)$ is expected.1h The observed trend for complexes 3, 11, and 12, which shows an increase in the absorption maximum energy with increasing $\Delta E_{1 / 2}$, is in accordance with the data previously reported for other $\mathrm{Ru}^{\mathrm{II}}$-polypyridine complexes. ${ }^{1 \mathrm{~h}}$

Complexes 3, 11, and $\mathbf{1 2}$ do not show light emission in solution at room temperature and at $77 \mathrm{~K}$, as expected for terpyridine-based $\mathrm{Ru}^{\mathrm{II}}$ complexes, due to the low energy gap between the ${ }^{3} \mathrm{MLCT}$ and the ${ }^{3} \mathrm{MC}$, which can then be thermally activated, leading to a nonradiative decay path. ${ }^{1,16}$ The lack of radiative decay in these complexes is consistent to some extent with the observation that $\sigma$-donors stronger than terpyridine (as PCP and NCN pincer ligands are) contribute to increase dramatically the nonradiative rate constant. ${ }^{1 \mathrm{~h}}$ Investigations on the photophysical processes occurring in a wider range of $\mathrm{NCN}$ and PCPRu ${ }^{\mathrm{II}}$ complexes are ongoing.

\section{Conclusions}

The influence of the auxiliary ligands on the reactivity of $\left[\mathrm{RuCl}(\mathrm{NCN})\left(\mathrm{PPh}_{3}\right)\right]$ and $\left[\mathrm{RuCl}(\mathrm{PCP})\left(\mathrm{PPh}_{3}\right)\right]$ com-

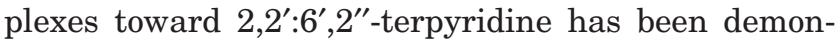
strated. New versatile synthetic strategies have been developed for the preparation of $[\mathrm{Ru}(\mathrm{PCP})(\mathrm{tpy})] \mathrm{Cl}$ complexes which show high stability to moisture and air. Substitution of the monoanionic bisaminoaryl ligand $\left[\mathrm{C}_{6} \mathrm{H}_{3}\left(\mathrm{CH}_{2} \mathrm{NMe}_{2}\right)_{2}-2,6\right]^{-}(\mathrm{NCN})$ by the monoanionic bisphosphinoaryl pincer ligand $\left[\mathrm{C}_{6} \mathrm{H}_{3}\left(\mathrm{CH}_{2} \mathrm{PR}_{2}\right)_{2}-2,6\right]^{-}(\mathrm{PCP})$ results in tunable and interesting electrochemical and spectroscopic behavior. The enhanced accepting character of the phosphorus atoms of the PCP ligands, which can be finely modulated by changing the substituents, accounts for the stabilization of $\mathrm{Ru}(\mathrm{d} \pi)$ orbitals, resulting in a more positive $\mathrm{Ru}^{\mathrm{III} / \mathrm{II}}$ redox couples and higher energy of the MLCT transitions.

\section{Experimental Section}

General Procedures. All experiments were carried out under a dry nitrogen atmosphere using standard Schlenk

(16) Excitation of the three complexes $\left(\lambda_{\text {exc }}=480 \mathrm{~nm}\right)$ in a butyronitrile glass at $77 \mathrm{~K}$ resulted in a weak emission centered at 600 $\mathrm{nm}$. If this emission arose from a ${ }^{3}$ MLCT decay in complexes $\mathbf{3}, \mathbf{1 1}$, and 12, one would expect the maximum to be shifted according to the different electronic properties of the PCP- and NCN-type ligands. However, by the shape and features of the emission, combined with the lifetime at $77 \mathrm{~K}$, it is likely that this emission was due to small impurities of highly emitting $\left[\mathrm{Ru}(\mathrm{tpy})_{2}\right]\left(\mathrm{PF}_{6}\right)_{2} \cdot{ }^{1 \mathrm{a}, \mathrm{h}}$ 
techniques. Benzene, toluene, pentane, hexane, diethyl ether, and tetrahydrofuran were distilled over sodium/benzophenone. Dichloromethane was dried over $\mathrm{CaH}_{2}$. Methanol was dried over magnesium and used freshly distilled. Compounds $\mathbf{3},{ }^{6}$ $5,{ }^{8 b, c}$ and $\mathbf{6}^{8 \mathrm{~b}, \mathrm{c}}$ and $\left[\mathrm{RuCl}(\mathrm{NCN})\left(\mathrm{PPh}_{3}\right)\right](\mathbf{7})$ and $\left[\mathrm{RuCl}(\mathrm{PCP})_{-}\right.$ $\left.\left(\mathrm{PPh}_{3}\right)\right](\mathbf{9})$ complexes $^{8 \mathrm{~g}}$ were prepared according to literature procedures. All other reagents were used as purchased. ${ }^{1} \mathrm{H}$ (200.1 or $300.1 \mathrm{MHz}),{ }^{13} \mathrm{C}(75 \mathrm{MHz})$, and ${ }^{31} \mathrm{P}(81 \mathrm{MHz}) \mathrm{NMR}$ spectra were recorded at $298 \mathrm{~K}$ on a Varian AC200 or Varian INOVA 300 spectrometer. Chemical shifts are in ppm relative to the residual solvent signal $\left({ }^{1} \mathrm{H}\right.$ and ${ }^{13} \mathrm{C}$ NMR spectra) or are externally referenced to $85 \% \mathrm{H}_{3} \mathrm{PO}_{4}$ solution in water ${ }^{31} \mathrm{P}$ NMR spectra). Elemental analyses were performed by Dornis und Kolbe, Mikroanalytisches Laboratorium, Müllheim a. d. Ruhr, Germany.

Cyclic Voltammetry Experiments. The electrochemical experiments were performed with an EG\&G potentiostat/ galvanostat model 263A controlled by model 270/250 Research Electrochemistry Software (version 4.23). A three-electrode system was used, consisting of a platinum (Pt) working electrode, a platinum (Pt) auxiliary electrode, and a $\mathrm{Ag} / \mathrm{AgCl}$ reference electrode separated from the test solution by a glass frit. The experiments were carried out in butyronitrile at room temperature in a nitrogen atmosphere with tetrabutylammonium hexafluorophosphate (TBAH) as electrolyte $(0.1 \mathrm{M})$. All potentials are reported relative to SCE. Linear voltammograms were obtained at a scan rate of $100 \mathrm{mV} \mathrm{s}^{-1}$.

Electronic Spectroscopic Measurements. UV-vis absorption spectra were obtained on a Varian Cary 1 spectrophotometer using matched $1 \mathrm{~cm}$ cells and operating with 0.5 $\mathrm{nm}$ spectral resolution. Peak positions are given with a 0.5 $\mathrm{nm}$ accuracy. Steady state luminescence was measured in butyronitrile glasses at $77 \mathrm{~K}$ using a SPEX fluorimeter. For nanosecond time-resolved emission measurements, a continuously tunable Coherent Infinity XPO laser (tuned at $450 \mathrm{~nm}$ ), with a pulse of $2 \mathrm{~ns}$ fwhm, was used as excitation source. Full spectra and decays were recorded using a Hamamatsu C568021 streak camera, equipped with a M 5677 sweep unit.

Crystal Structure Determinations. X-ray intensities were measured on a Nonius KappaCCD diffractometer with rotating anode and $\mathrm{Mo} \mathrm{K} \alpha$ radiation (graphite monochromator, $\lambda=0.71073 \AA$ ) at a temperature of $150(2) \mathrm{K}$. The structures were solved with automated Patterson methods ${ }^{17}$ (compound 4) or direct methods ${ }^{18}$ (compound 14) and refined with SHELXL-9 $7^{19}$ against $F^{2}$ of all reflections. Non-hydrogen atoms were refined freely with anisotropic displacement parameters, and hydrogen atoms were refined as rigid groups. The drawings, structure calculations, and checking for higher symmetry were performed with the program PLATON. ${ }^{20}$

Compound 4: $\mathrm{C}_{33} \mathrm{H}_{26} \mathrm{Cl}_{2} \mathrm{~N}_{3} \mathrm{PRu} \cdot 0.5 \mathrm{CH}_{2} \mathrm{Cl}_{2} \cdot 0.3 \mathrm{C}_{4} \mathrm{H}_{10} \mathrm{O}+$ disordered solvent, $\mathrm{fw}=732.21$, dark red block, $0.39 \times$ $0.24 \times 0.12 \mathrm{~mm}^{3}$, monoclinic, space group $C 2 / c$ (no. 15), $a=$ 34.885(3) $\AA, b=13.6771(15) \AA, c=35.108(3) \AA, \beta=117.326$ $(9)^{\circ}, V=14882(3) \AA^{3}, Z=16, \rho=1.307 \mathrm{~g} / \mathrm{cm}^{3}$. An absorption correction based on multiple measured reflections was applied $\left(\mu=0.71 \mathrm{~mm}^{-1}\right.$, correction range $\left.0.76-0.92\right)$. A total of 51763 reflections were measured up to a resolution of $\sin \theta / \lambda=0.61$ $\AA^{-1}$, of which 13711 were unique $\left(R_{\text {int }}=0.048\right)$. Some of the solvent molecules were refined as discrete molecules; others were heavily disordered and included using the SQUEEZE routine of PLATON ${ }^{20}$ (back-Fourier transformation of 503 $\mathrm{e}^{-} /$unit cell distributed over voids of $2363.2 \AA^{3} /$ unit cell).

(17) Beurskens, P. T.; Admiraal, G.; Beurskens, G.; Bosman, W. P. Garcia-Granda, S.; Gould, R. O.; Smits, J. M. M.; Smykalla, C. The DIRDIF99 program system, Technical Report of the Crystallography Laboratory; University of Nijmegen: The Netherlands, 1999.

(18) Sheldrick, G. M. SHELXS-97, Program for crystal structure solution; University of Göttingen: Germany, 1997.

(19) Sheldrick, G. M. SHELXL-97, Program for crystal structure refinement; University of Göttingen: Germany 1997.

(20) Spek, A. L. J. Appl. Crystallogr. 2003, 36, 7.
Refined parameters: 768. Restraints: $3 . R$ (obsd reflns): $\mathrm{R} 1=0.0465, \mathrm{wR} 2=0.1444 . \quad R$ (all data): $\mathrm{R} 1=0.0715$, $\mathrm{wR} 2=0.1541$. Weighting scheme $w=1 /\left[\sigma^{2}\left(F_{0}{ }^{2}\right)+(0.0912 P)^{2}\right]$, where $P=\left(F_{\mathrm{o}}{ }^{2}+2{F_{\mathrm{c}}}^{2}\right) / 3$. GoF $=1.139$. Residual electron density between -0.51 and $1.64 \mathrm{e}^{\circ} \AA^{3}$.

Compound 14: $\left[\mathrm{C}_{47} \mathrm{H}_{38} \mathrm{~N}_{3} \mathrm{P}_{2} \mathrm{Ru}\right]\left[\mathrm{CF}_{3} \mathrm{O}_{3} \mathrm{~S}\right]+$ disordered solvent, $\mathrm{fw}=956.88$, red plate, $0.15 \times 0.15 \times 0.03 \mathrm{~mm}^{3}$, triclinic, space group $P \overline{1}$ (no. 2), $a=10.1323(1) \AA, b=11.2911$ (2) $\AA, c$ $=20.5214(3) \AA, \alpha=83.4955(6)^{\circ}, \beta=84.9604(6)^{\circ}, \gamma=88.7150$ $(5)^{\circ}, V=2323.43(6) \AA^{3}, Z=2, \rho=1.368 \mathrm{~g} / \mathrm{cm}^{3}$. An absorption correction based on multiple measured reflections was applied $\left(\mu=0.51 \mathrm{~mm}^{-1}\right.$, correction range $\left.0.94-1.00\right)$. A total of 38869 reflections were measured up to a resolution of $\sin \theta / \lambda=0.65$ $\AA^{-1}$, of which 10415 were unique $\left(R_{\text {int }}=0.064\right)$. The triflate anion was disordered over two positions with a population of 0.67:0.33. The crystal structure contains large voids $\left(304.3 \AA^{3 /}\right.$ unit cell) filled with disordered solvent molecules. Their contribution to the structure factors was secured by backFourier transformation (program PLATON ${ }^{19}$ CALC SQUEEZE, $68 \mathrm{e}^{-} /$unit cell). Refined parameters: 614 . Restraints: $175 . R$ (obsd reflns): $\mathrm{R} 1=0.0393, \mathrm{wR} 2=0.0840 . R$ (all data): $\mathrm{R} 1=$ $0.0646, \mathrm{wR} 2=0.0932$. Weighting scheme $w=1 /\left[\sigma^{2}\left(F_{\mathrm{o}}{ }^{2}\right)+\right.$ $\left.(0.0421 P)^{2}\right]$, where $P=\left(F_{0}^{2}+2 F_{\mathrm{c}}^{2}\right) / 3 . \mathrm{GoF}=1.047$. Residual electron density between -0.59 and $0.60 \mathrm{e} / \AA^{3}$.

Synthesis of $\left[\mathbf{R u}\left\{\mathrm{C}_{6} \mathrm{H}_{3}\left(\mathrm{CH}_{2} \mathbf{P P h}_{2}\right)_{2}-\mathbf{2 , 6}\right\}(\mathrm{tpy})\right](\mathrm{Cl})$ (11). To a solution of complex $\left[\mathrm{RuCl}\left\{\mathrm{C}_{6} \mathrm{H}_{3}\left(\mathrm{CH}_{2} \mathrm{PPh}_{2}\right)_{2}-2,6\right\}\left(\mathrm{PPh}_{3}\right)\right](\mathbf{9})$ $(90 \mathrm{mg}, 0.1 \mathrm{mmol})$ in $\mathrm{MeOH}(15 \mathrm{~mL})$ was added a solution of tpy $(25 \mathrm{mg}, 0.1 \mathrm{mmol})$ in $\mathrm{MeOH}(5 \mathrm{~mL})$. The reaction mixture was stirred at reflux temperature for 3 days. The solvent was then evaporated in vacuo to give a red solid residue, stable in air and water, which was dissolved in $5 \mathrm{~mL}$ of $\mathrm{CH}_{2} \mathrm{Cl}_{2}$. Addition of pentane/Et $t_{2} \mathrm{O}(1: 5)$ resulted in precipitation of an air-stable red powder, which was collected by filtration, washed with hexane, and dried in vacuo $\left(72 \mathrm{mg}, 86 \%\right.$ yield). ${ }^{1} \mathrm{H}$ NMR $(200$ $\left.\mathrm{MHz}, \mathrm{CD}_{2} \mathrm{Cl}_{2}\right): \delta 8.73\left(\mathrm{~d}, 2 \mathrm{H},{ }^{3} J_{\mathrm{H}-\mathrm{H}}=8.0 \mathrm{~Hz}, \operatorname{PyrH}\left(3^{\prime}, 5^{\prime}\right)\right)$, $8.39\left(\mathrm{t}, 1 \mathrm{H},{ }^{3} J_{\mathrm{H}-\mathrm{H}}=8.3 \mathrm{~Hz}, \operatorname{PyrH}\left(4^{\prime}\right)\right), 8.24\left(\mathrm{~d}, 2 \mathrm{H},{ }^{3} J_{\mathrm{H}-\mathrm{H}}=\right.$ $8.4 \mathrm{~Hz}, \operatorname{PyrH}(6)), 7.54-7.05$ (m, 9H, $\operatorname{PyrH}(3,4,5), \operatorname{ArH}), 6.92$ (t, $\left.10 \mathrm{H},{ }^{3} J_{\mathrm{H}-\mathrm{H}}=7.0 \mathrm{~Hz}, \mathrm{ArH}\right), 6.57-6.40(\mathrm{~m}, 10 \mathrm{H}, \mathrm{ArH}), 4.00$ $\left(\mathrm{t}, 4 \mathrm{H},{ }^{3} J_{\mathrm{H}-\mathrm{H}}=4.1 \mathrm{~Hz}, \mathrm{CH}_{2}\right) .{ }^{13} \mathrm{C} \mathrm{NMR}\left(75.4 \mathrm{MHz}, \mathrm{CD}_{2} \mathrm{Cl}_{2}\right): \delta$ $182.1\left(\mathrm{t},{ }^{2} J_{\mathrm{C}-\mathrm{P}}=5.9 \mathrm{~Hz}, \mathrm{C}_{\mathrm{ipso}}\right), 157.9,155.0,153.0,147.4(\mathrm{t}$, $\left.{ }^{2} J_{\mathrm{C}-\mathrm{P}}=9.1 \mathrm{~Hz}\right), 135.1,134.1,132.9\left(\mathrm{t},{ }^{3} J_{\mathrm{C}-\mathrm{P}}=17.0 \mathrm{~Hz}\right), 130.5$ $\left(\mathrm{t},{ }^{3} J_{\mathrm{C}-\mathrm{P}}=4.8 \mathrm{~Hz}\right), 129.8,128.8\left(\mathrm{t},{ }^{3} J_{\mathrm{C}-\mathrm{P}}=4.2 \mathrm{~Hz}\right), 126.7,123.8$, 123.5, 122.9, $122.8\left(\mathrm{t},{ }^{3} J_{\mathrm{C}-\mathrm{P}}=7.9 \mathrm{~Hz}\right), 41.98\left(\mathrm{t},{ }^{3} J_{\mathrm{C}-\mathrm{P}}=17.0\right.$ Hz). ${ }^{31} \mathrm{P}$ NMR $\left(81 \mathrm{MHz}, \mathrm{CD}_{2} \mathrm{Cl}_{2}\right): \delta 42.9$. Anal. Calcd for $\mathrm{C}_{47} \mathrm{H}_{38-}$ $\mathrm{ClN}_{3} \mathrm{P}_{2} \mathrm{Ru}$ : C, 66.94; H, 4.54; N, 4.98. Found: C, 67.12; H, 4.68; $\mathrm{N}, 5.11$.

Synthesis of $\left[\mathrm{Ru}\left\{\mathrm{C}_{6} \mathrm{H}_{3}\left(\mathrm{CH}_{2} \mathrm{PiPr}_{2}\right)_{2}-2,6\right\}(\mathrm{tpy})\right](\mathrm{Cl})$ (12). The air-stable complex 12 was prepared by applying the synthetic procedure described for complex 11 employing $95 \mathrm{mg}$ $(0.26 \mathrm{mmol})$ of $10 \mathrm{in} \mathrm{MeOH}(15 \mathrm{~mL})$ and $60 \mathrm{mg}$ of tpy $(0.26$ $\mathrm{mmol})$ in $\mathrm{MeOH}(5 \mathrm{~mL})(155 \mathrm{mg}, 84 \%$ yield $) .{ }^{1} \mathrm{H}$ NMR $(200$ $\left.\mathrm{MHz}, \mathrm{CD}_{2} \mathrm{Cl}_{2}\right): \delta 8.72\left(\mathrm{~d}, 2 \mathrm{H},{ }^{3} \mathrm{~J}_{\mathrm{H}-\mathrm{H}}=8.0 \mathrm{~Hz}, \mathrm{PyrH}\left(3^{\prime}, 5^{\prime}\right)\right), 8.63$ $\left(\mathrm{d}, 2 \mathrm{H},{ }^{3} \boldsymbol{J}_{\mathrm{H}-\mathrm{H}}=7.7 \mathrm{~Hz}, \operatorname{PyrH}(6)\right), 8.26\left(\mathrm{~d}, 2 \mathrm{H},{ }^{3} \boldsymbol{J}_{\mathrm{H}-\mathrm{H}}=4.75\right.$ $\mathrm{Hz}, \operatorname{PyrH}(5)), 8.16\left(\mathrm{t}, 1 \mathrm{H},{ }^{3} J_{\mathrm{H}-\mathrm{H}}=8.0 \mathrm{~Hz}, \operatorname{PyrH}\left(4^{\prime}\right)\right), 7.99(\mathrm{t}$, $\left.2 \mathrm{H},{ }^{3} J_{\mathrm{H}-\mathrm{H}}=7.8 \mathrm{~Hz}, \mathrm{PyrH}(4)\right), 7.31\left(\mathrm{t}, 2 \mathrm{H},{ }^{3} J_{\mathrm{H}-\mathrm{H}}=6.7 \mathrm{~Hz}, \mathrm{Pyr}\right.$ $\mathrm{H}(3)), 7.23\left(\mathrm{~d}, 2 \mathrm{H},{ }^{3} J_{\mathrm{H}-\mathrm{H}}=7.0 \mathrm{~Hz}, \mathrm{ArH}\right), 6.96\left(\mathrm{t}, 1 \mathrm{H},{ }^{3} J_{\mathrm{H}-\mathrm{H}}=\right.$ $7.1 \mathrm{~Hz}, \mathrm{ArH}), 3.28\left(\mathrm{~m}, 4 \mathrm{H}, \mathrm{CH}_{2}\right), 1.48(\mathrm{~m}, 4 \mathrm{H}, \mathrm{CH}), 0.59$ (dd, $\left.12 \mathrm{H},{ }^{3} J_{\mathrm{H}-\mathrm{H}}=6.23 \mathrm{~Hz},{ }^{3} J_{\mathrm{H}-\mathrm{P}}=20.16 \mathrm{~Hz}, \mathrm{CH}_{3}\right), 0.11(\mathrm{dd}, 12 \mathrm{H}$, $\left.{ }^{3} J_{\mathrm{H}-\mathrm{H}}=6.60 \mathrm{~Hz},{ }^{3} J_{\mathrm{H}-\mathrm{P}}=20.26 \mathrm{~Hz}, \mathrm{CH}_{3}\right) .{ }^{13} \mathrm{C} \mathrm{NMR}(75.4 \mathrm{MHz}$, $\left.\mathrm{CD}_{2} \mathrm{Cl}_{2}\right): \delta 182.7\left(\mathrm{~m}, \mathrm{C}_{\mathrm{ipso}}\right), 159.51,154.54,153.54,146.65(\mathrm{t}$, $\left.{ }^{3} J_{\mathrm{C}-\mathrm{P}}=8.5 \mathrm{~Hz}\right), 135.1,135.55,132.0,126.68,124.01,122.82$, $122.31,122.21,122.16,37.68\left(\mathrm{t},{ }^{3} J_{\mathrm{C}-\mathrm{P}}=14.6 \mathrm{~Hz}, \mathrm{CH}_{2}\right), 23.48$ $\left(\mathrm{t},{ }^{3} J_{\mathrm{C}-\mathrm{P}}=8.5 \mathrm{~Hz}, \mathrm{P}-\mathrm{CH}\right), 18.40\left(\mathrm{~d},{ }^{3} J_{\mathrm{C}-\mathrm{P}}=11.6 \mathrm{~Hz}, \mathrm{P}-\mathrm{CH}_{3}\right)$. ${ }^{31} \mathrm{P}$ NMR $\left(81 \mathrm{MHz}, \mathrm{CD}_{2} \mathrm{Cl}_{2}\right): \delta$ 51.63. Anal. Calcd for $\mathrm{C}_{35} \mathrm{H}_{46^{-}}$ $\mathrm{ClN}_{3} \mathrm{P}_{2} \mathrm{Ru}$ : C, 59.44; H, 6.56; N, 5.94. Found: C, 59.59; H, 6.51; $\mathrm{N}, 6.09$.

Synthesis of [Ru $\left\{\mathrm{C}_{6} \mathrm{H}_{3}\left(\mathrm{CH}_{2} \mathrm{PPh}_{2}\right)_{2^{-2}}, 6\right\}$ (tpy)](OTf) (14). Method a. $\mathrm{Me}_{3} \operatorname{SiOTf}(136 \mathrm{mg}, 0.6 \mathrm{mmol}$ ) was added to a solution of complex $\left[\mathrm{RuCl}\left\{\mathrm{C}_{6} \mathrm{H}_{3}\left(\mathrm{CH}_{2} \mathrm{PPh}_{2}\right)_{2}-2,6\right\}\left(\mathrm{PPh}_{3}\right)\right](\mathbf{9})(179$ $\mathrm{mg}, 0.2 \mathrm{mmol})$ in $\mathrm{C}_{6} \mathrm{H}_{6}(15 \mathrm{~mL})$. The reaction mixture was stirred at room temperature for $3 \mathrm{~h}$. All the volatiles were 
evaporated in vacuo, and the obtained green residue washed with hexane. A solution of tpy (46 mg, $0.2 \mathrm{mmol}$ ) in $\mathrm{MeOH}$ $(15 \mathrm{~mL})$ was added to the dried green solid residue, and the obtained mixture was subsequently stirred at room temperature for $3 \mathrm{~h}$. The color of the reaction mixture turned instantaneously from green to deep red. The solvent was removed in vacuo and the red solid residue dissolved in $5 \mathrm{~mL}$ of $\mathrm{CH}_{2} \mathrm{Cl}_{2}$. The air- and water-stable red powder which precipitated by addition of a pentane/ $\mathrm{Et}_{2} \mathrm{O}$ (1:5) solution was collected by filtration, washed with hexane, and dried in vacuo (163 mg, 90\% yield).

Method b. AgOTf (130 mg, $0.4 \mathrm{mmol}$ ) was added to a stirred solution of $\left[\mathrm{RuCl}\left\{\mathrm{C}_{6} \mathrm{H}_{3}\left(\mathrm{CH}_{2} \mathrm{PPh}_{2}\right)_{2}-2,6\right\}\left(\mathrm{PPh}_{3}\right)\right](8)(352 \mathrm{mg}, 0.4$ $\mathrm{mmol}$ ) and tpy (105 mg, $0.45 \mathrm{mmol})$ in $\mathrm{MeOH}(20 \mathrm{~mL})$. An instantaneous color change of the reaction mixture from green to red was observed. After stirring at room temperature for 3 $\mathrm{h}$, the red solution was separated from the $\mathrm{AgCl}$ formed by filtration over Celite. $\mathrm{MeOH}$ was removed in vacuo and the residue dissolved in $5 \mathrm{~mL}$ of $\mathrm{CH}_{2} \mathrm{Cl}_{2}$. Addition of pentane/Et $\mathrm{t}_{2} \mathrm{O}$ (1:5) resulted in precipitation of an air-stable red powder (321 $\mathrm{mg}, 86 \%$ yield), which was collected by filtration, washed with hexane, and dried in vacuo. NMR data of the obtained complex
14 prepared by applying both synthetic procedures were consistent with values earlier reported. ${ }^{9}$ Crystals suitable for $\mathrm{X}$-ray diffraction determination were obtained by slow diffusion of diethyl ether vapor into a solution of 14 in $\mathrm{CH}_{2} \mathrm{Cl}_{2}$. A selection of bond lengths, angles, and torsion angles is summarized in Table 2.

Acknowledgment. The authors kindly acknowledge Dr. F. Hartl and Dr. C. A. van Walree for their assistance during CV measurements. This work was supported by the Council for Chemical Sciences from the Dutch Organization for Scientific Research (CWNWO).

Supporting Information Available: Cif files of crystal data collection and refinement parameters, atomic coordinates, bond lengths and angles, and anisotropic displacement parameters for complexes 4 and 14. This material is available free of charge via the Internet at http://pubs.acs.org.

OM049503U 